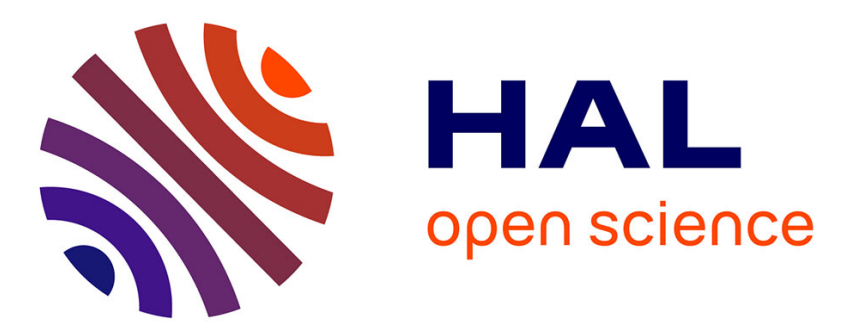

\title{
An Efficient Method for the Synthesis of 2-Methylallyl Alkenes by Cross-Coupling Reactions
}

Clemence Tabélé, Christophe Curti, Nicolas Primas, Youssef Kabri, Vincent Remusat, Patrice Vanelle

\section{To cite this version:}

Clemence Tabélé, Christophe Curti, Nicolas Primas, Youssef Kabri, Vincent Remusat, et al.. An Efficient Method for the Synthesis of 2-Methylallyl Alkenes by Cross-Coupling Reactions. Synthesis: Journal of Synthetic Organic Chemistry, 2015, 47, pp.3339 - 3346. 10.1055/s-0034-1381034 . hal01423338

\section{HAL Id: hal-01423338 \\ https://hal.science/hal-01423338}

Submitted on 29 Dec 2016

HAL is a multi-disciplinary open access archive for the deposit and dissemination of scientific research documents, whether they are published or not. The documents may come from teaching and research institutions in France or abroad, or from public or private research centers.
L'archive ouverte pluridisciplinaire HAL, est destinée au dépôt et à la diffusion de documents scientifiques de niveau recherche, publiés ou non, émanant des établissements d'enseignement et de recherche français ou étrangers, des laboratoires publics ou privés. 


\section{An Efficient Method for the Synthesis of 2-Methylallyl Alkenes by Cross-Coupling Reactions}

\author{
Clemence Tabélé \\ Christophe Curti \\ Nicolas Primas \\ Youssef Kabri \\ Vincent Remusat \\ Patrice Vanelle*
}<smiles>OB(O)c1ccbcc1</smiles>

Aix-Marseille Université, CNRS, ICR, UMR 7273,

Laboratoire de Pharmaco-Chimie Radicalaire,

Faculté de Pharmacie, 27 Boulevard Jean Moulin -

CS30064, 13385 Marseille Cedex 05, France

patrice.vanelle@univ-amu.fr

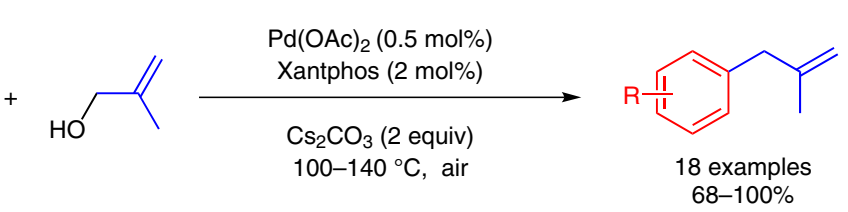

atives showed that the $\mathrm{R}^{1}$ aromatic moiety must be linked to the dihydrofuran by a methylene group to retain the antileishmanial activity (Scheme 1$){ }^{5}$

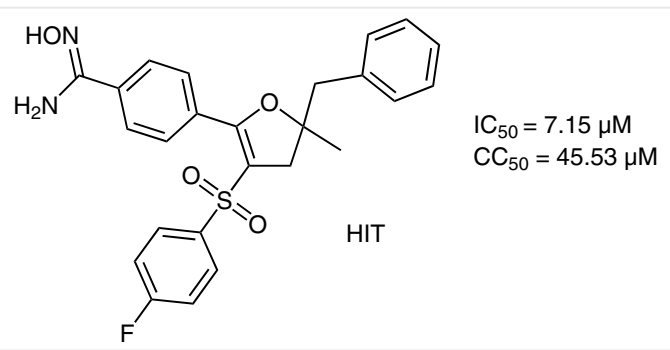

Figure 1 4-[5-Benzyl-3-(4-fluorophenylsulfonyl)-5-methyl-4,5-dihydrofuran-2-yl]- $N^{\prime}$-hydroxybenzimidamide

In connection with our program centered on the preparation of new, potentially bioactive compounds, ${ }^{6}$ aiming at exploring deeper SARs of the amidoxime series, we needed to synthesize new compounds using various 2-methylallyl derivatives. However, few aromatic 2-methylallyl derivatives are commercially available and very few publications have addressed the synthesis of these particular alkenes. ${ }^{7}$

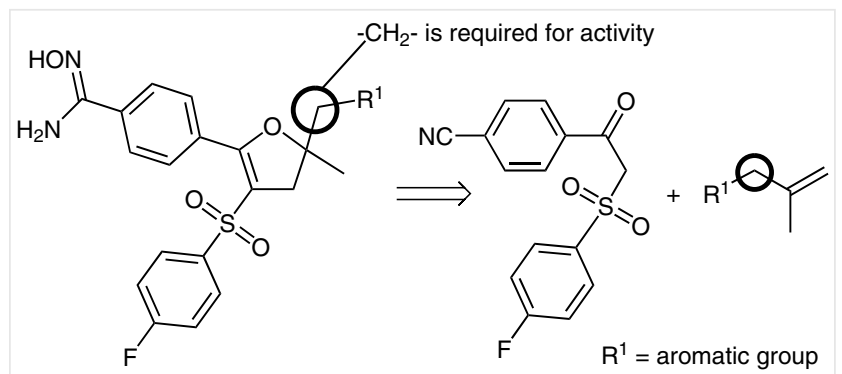

Scheme 1 Alkene structure required for the synthesis of new amidoxime derivatives 
The use of methallyl alcohol (2-methyl-2-propen-1-ol) in cross-coupling reactions is a real challenge, since it is known to be a poor reactive substrate as hydroxy is a poor leaving group. ${ }^{\text {th }}$ In light of the above, we decided to synthesize a new series of alkenes by employing cross-coupling reactions between 2-methyl-2-propen-1-ol and various organoboronic acids. Cross-coupling reactions between allyl alcohols and organoboronic acids have already been described; ${ }^{7 \mathrm{f}-\mathrm{h}, 8}$ unfortunately, starting from the previous protocols, using no base ${ }^{7 f-h}$ or catalytic amounts of base in water, ${ }^{8}$ we did not obtain the required cross-coupled products. For example, 0 -methylphenylboronic acid or $p$-nitrophenylboronic acid did not react with methallyl alcohol in the presence of $\mathrm{Pd}_{2}(\mathrm{dba})_{3} \cdot \mathrm{CHCl}_{3} /(\mathrm{PhO})_{3} \mathrm{P}$ in toluene at $100{ }^{\circ} \mathrm{C} . .^{\mathrm{g}}$ Similarly, o-methylphenylboronic acid or $p$-cyanophenylboronic acid did not react with methallyl alcohol in the presence of $\mathrm{Pd}\left(\mathrm{Ph}_{3}\right)_{4}$ in refluxing dioxane or tetrahydrofuran. ${ }^{7 \mathrm{fth}}$ We hypothesized that the lower cross-coupling reactivity of methallyl alcohol relative to other allyl alcohols and/or the versatility of the substituted boronic acid reactivity are involved. ${ }^{7 f}$

A new protocol has now been established, allowing the use of a wider range of organoboronic acids. Our prior experience with palladium-catalyzed cross-coupling reactions has facilitated the synthesis of new alkenes. ${ }^{9}$

Phenylboronic acid was initially chosen as it is the simplest arylboronic acid, without any substituent that could influence reactivity (Scheme 2). Previous studies on allylic alcohol cross-coupling reactivity have investigated various organic solvents such as toluene, dioxane or dichloromethane. In an elegant study, Manabe and co-workers ${ }^{8}$ have also described the first cross-coupling reaction of an allylic alcohol in water. Following their lead, we decided to use water or another environmentally benign solvent.

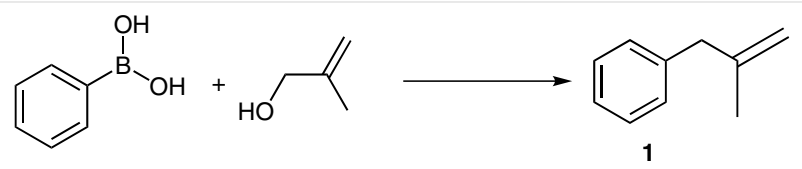

Scheme 2 Synthesis of (2-methylallyl)benzene (1)

Our preliminary investigations had shown that 2-methyl-2-propen-1-ol did not react with substituted boronic acids under classical conditions without the presence of a base. Therefore, the influence of temperature and base needed to be assessed first (Table 1 ).

Assays pointed to a need for heating to carry out the cross-coupling reaction (Table 1 , entries 1-4). The outcomes highlighted the need for a strong base for an optimal cross-coupling reaction: the yield was increased twofold by replacing potassium carbonate with cesium carbonate (Table 1 , entries 4 and 9). ${ }^{10}$ Although the exact role of the base remains unclear, yields of cross-coupling reactions of allylic
Table 1 Assessment of the Influence of Temperature and Base $\mathrm{a}^{\mathrm{a}}$

\begin{tabular}{lllcc}
\hline Entry & Base & Temp $\left({ }^{\circ} \mathrm{C}\right)$ & Time (h) & Yield (\%) of $\mathbf{1}$ \\
\hline 1 & none & r.t. & 12 & 0 \\
2 & $\mathrm{~K}_{2} \mathrm{CO}_{3}$ (2 equiv) & r.t. & 3 & 0 \\
3 & $\mathrm{~K}_{2} \mathrm{CO}_{3}$ (2 equiv) & 140 & 1.5 & 2 \\
4 & $\mathrm{~K}_{2} \mathrm{CO}_{3}$ (2 equiv) & $140^{\mathrm{b}}$ & 1 & 11 \\
5 & $\mathrm{NaOH}$ (0.05 equiv) & $140^{\mathrm{b}}$ & 1.5 & 0 \\
6 & $\mathrm{NaOH}$ (1 equiv) & $140^{\mathrm{b}}$ & 1.5 & 5 \\
7 & $\mathrm{NaOH}$ (2 equiv) & $140^{\mathrm{b}}$ & 1.5 & 11 \\
8 & $t-\mathrm{BuOK}^{\mathrm{b}}$ (2 equiv) & $140^{\mathrm{b}}$ & 1 & 7 \\
9 & $\mathrm{Cs}_{2} \mathrm{CO}_{3}$ (2 equiv) & $140^{\mathrm{b}}$ & 1 & 22 \\
\hline
\end{tabular}

a Typical reaction conditions: $\mathrm{H}_{2} \mathrm{O}$ as solvent, $\mathrm{N}_{2}$ atmosphere, $\mathrm{Pd}\left(\mathrm{PPh}_{3}\right)_{4}(5$ $\mathrm{mol} \%$ ) as the catalyst system.

${ }^{b}$ Reaction implemented under microwave irradiation in a sealed reactor.

alcohols in water are supposed to be increased with a catalytic amount of base. ${ }^{8}$ Herein, stoichiometric amounts of a strong base were needed, probably because of the low reactivity of methallyl alcohol. Subsequent cross-coupling reactions were conducted with 2 equivalents of cesium carbonate at $140{ }^{\circ} \mathrm{C}$ under microwave irradiation for one hour. The catalyst system conditions were then assessed by using various phosphine types of ligand (Table 2).

Table 2 Assessment of the Influence of the Catalyst System ${ }^{\text {a }}$

\begin{tabular}{cllc}
\hline Entry & Catalyst & Additional ligand & Yield (\%) of 1 \\
\hline 1 & - & - & 0 \\
2 & $\mathrm{Pd}_{2}(\mathrm{dba})_{3}$ & - & 2 \\
3 & $\mathrm{Pd}_{2}(\mathrm{dba})_{3}$ & $\mathrm{Ph}_{3} \mathrm{P}$ & 18 \\
4 & $\mathrm{Pd}_{2}(\mathrm{dba})_{3}$ & BINAP & 24 \\
5 & $\mathrm{Pd}(\mathrm{OAc})_{2}$ & - & 7 \\
6 & $\mathrm{Pd}(\mathrm{OAc})_{2}$ & $\mathrm{Ph}_{3} \mathrm{P}$ & 9 \\
7 & $\mathrm{Pd}(\mathrm{OAc})_{2}$ & BINAP & 11 \\
8 & $\mathrm{Pd}(\mathrm{dppf})_{\mathrm{Cl}_{2}}$ & - & 13 \\
9 & $\mathrm{Pd}(\mathrm{PPh})_{2} \mathrm{Cl}_{2}$ & - & 22 \\
10 & $\mathrm{Pd}(\mathrm{dppf})_{\mathrm{Cl}_{2}}$ & $\mathrm{Ph}_{3} \mathrm{P}$ & 9 \\
11 & $\mathrm{Pd}(\mathrm{OAc})_{2}$ & Xantphos $_{2}$ & 29 \\
\hline
\end{tabular}

a Typical reaction conditions: $\mathrm{H}_{2} \mathrm{O}$ as solvent, $\mathrm{N}_{2}$ atmosphere, $\mathrm{Cs}_{2} \mathrm{CO}_{3}$ as base, catalyst ( $5 \mathrm{~mol} \%$ ), additional ligand (10 mol\%) if applicable, heating at $140{ }^{\circ} \mathrm{C}$ under microwave irradiation for $1 \mathrm{~h}$ in a sealed reactor.

There was no cross-coupling reaction without a catalyst (Table 2, entry 1 ), which excludes an addition/elimination pathway. ${ }^{11}$ Reactions were more efficient when palladium(II) combined with a ligand was used, and bidentate ligands showed a better catalytic activity (Table 2, entries 211). Bidentate ligands such as Xantphos, usually used for palladium-catalyzed carbon-nitrogen ${ }^{12}$ bond-forming reactions, have also previously proven to be effective in carbon- 
carbon bond formation. Thus, subsequent cross-coupling reactions were conducted with palladium(II) acetate as catalyst and Xantphos as ligand. Atmospheric conditions and solvents were then assessed (Table 3 ).

Table 3 Assessment of the Influence of Solvent ${ }^{a}$

\begin{tabular}{llll}
\hline Entry & Solvent & Atmosphere & Yield (\%) of 1 \\
\hline 1 & $\mathrm{H}_{2} \mathrm{O}$ & air & 55 \\
2 & PEG 400 & air & 33 \\
3 & 2-methyl-2-propen-1-ol & air & 66 \\
\hline
\end{tabular}

a Typical reaction conditions: $\mathrm{Cs}_{2} \mathrm{CO}_{3}$ as base, $\mathrm{Pd}(\mathrm{OAc})_{2}(5 \mathrm{~mol} \%)$ as catalyst, Xantphos (10 mol\%) as ligand, heating at $140{ }^{\circ} \mathrm{C}$ under microwave irradiation for $1 \mathrm{~h}$ in a sealed reactor.

Cross-coupling reactions are usually carried out under inert atmosphere because palladium catalysts could be airsensitive. ${ }^{\text {bb,c }}$ Surprisingly, yields were higher for reactions under air atmosphere (Table 3, entry 1 ) than under nitrogen atmosphere (Table 2, entry 11 ), which suggests that oxygen in the air could enhance reactivity.

Using methallyl alcohol without any additive solvent provided the best yield (Table 3, entry 3), and a two-step distillation process under reduced pressure allowed the product to be quickly obtained in good yield. First, 2-methyl-2-propen-1-ol is withdrawn at $80^{\circ} \mathrm{C} / 600$ torr and then the cross-coupled product is obtained at $180^{\circ} \mathrm{C} / 600$ torr. It should be emphasized that distilled solvent (2-methyl-2propen-1-ol) can be recycled for at least three cross-coupling assays without any loss of reactivity. Subsequent cross-coupling reactions were therefore carried out under air conditions and with no additive solvent, using 2-methyl-2-propen-1-ol as both reagent and solvent.

As it has been clearly established that the amount of catalyst/ligand significantly affects yields, several assays were carried out to determine the best catalyst/ligand ratio (Table 4). ${ }^{\text {7h,13 }}$

Table 4 Assessment of the Influence of the Catalyst/Ligand Ratio ${ }^{\mathrm{a}}$

\begin{tabular}{llll}
\hline Entry & $\mathrm{Pd}(\mathrm{OAc})_{2}(\mathrm{~mol} \%)$ & Xantphos (mol\%) & Yield (\%) of 1 \\
\hline 1 & 1 & 2 & 65 \\
2 & 0.5 & 1 & 65 \\
3 & 0.5 & 2 & 88 \\
4 & 0.05 & 0.2 & 66 \\
\hline
\end{tabular}

${ }^{a}$ Typical reaction conditions: no additive solvent, air atmosphere, $\mathrm{Cs}_{2} \mathrm{CO}_{3}$ as base, $\mathrm{Pd}(\mathrm{OAc})_{2}$ as catalyst, Xantphos as ligand, heating at $140{ }^{\circ} \mathrm{C}$ under microwave irradiation for $1 \mathrm{~h}$ in a sealed reactor.

The most efficient ratio found was ligand/catalyst $4: 1$, which provided a greatly improved yield (Table 4, entry 3 ). Hence, subsequent cross-coupling reactions were carried out using this ligand/catalyst ratio.
The range of the reaction was explored using various organoboronic acids under the optimal reaction conditions previously established (Table 5); as before, purification of the cross-coupled products was carried out by distillation.

Table 5 Cross-Coupled Products from the Reaction of 2-Methyl-2propen-1-ol with Organoboronic Acids

\begin{tabular}{|c|c|c|c|}
\hline Entry & $R$ & Product & Yield (\%) \\
\hline 1 & $o$-Me & 2 & $86^{a}$ \\
\hline 2 & $m$-Me & 3 & $74^{\mathrm{b}}$ \\
\hline 3 & $p$-Me & 4 & $100^{\mathrm{a}}$ \\
\hline 4 & $o-B r$ & 5 & $81^{b}$ \\
\hline 5 & $\mathrm{p}-\mathrm{Br}$ & 6 & $92^{\mathrm{a}}$ \\
\hline 6 & $\mathrm{O}-\mathrm{NO}_{2}$ & 7 & $92^{c}$ \\
\hline 7 & $m-\mathrm{NO}_{2}$ & 8 & $76^{\mathrm{a}}$ \\
\hline 8 & $p-\mathrm{NO}_{2}$ & 9 & $70^{\mathrm{a}}$ \\
\hline 9 & $p$-Ph & 10 & $94^{\mathrm{a}}$ \\
\hline 10 & $o-\mathrm{CN}$ & 11 & $68^{c}$ \\
\hline 11 & $m-\mathrm{CN}$ & 12 & $85^{\mathrm{a}}$ \\
\hline 12 & $p-C N$ & 13 & $95^{\mathrm{a}}$ \\
\hline 13 & $p-\mathrm{CH}=\mathrm{CH}_{2}$ & 14 & $77^{a}$ \\
\hline 14 & $p-\mathrm{B}(\mathrm{OH})_{2}{ }^{\mathrm{d}}$ & 15 & $77^{\mathrm{a}}$ \\
\hline 15 & $\mathrm{o}-\mathrm{CH}_{2} \mathrm{OH}$ & 16 & $0^{a, c}$ \\
\hline 16 & $m-\mathrm{CH}_{2} \mathrm{OH}$ & 17 & $0^{\mathrm{a}, \mathrm{c}}$ \\
\hline 17 & $p-\mathrm{CH}_{2} \mathrm{OH}$ & 18 & $14^{\mathrm{a}}$ \\
\hline
\end{tabular}

a Reaction conditions (a): $\mathrm{Cs}_{2} \mathrm{CO}_{3}$ (2 equiv), $\mathrm{Pd}(\mathrm{OAc})_{2}$ (0.5 mol\%), Xantphos ( $2 \mathrm{~mol} \%$ ), sealed reactor, air, $\mathrm{MW}, 140^{\circ} \mathrm{C}, 1.5 \mathrm{~h}$.

${ }^{\mathrm{b}}$ Reaction conditions (b): $\mathrm{Cs}_{2} \mathrm{CO}_{3}$ (2 equiv), $\mathrm{Pd}(\mathrm{OAc})_{2}$ (0.5 mol\%), Xantphos (2 mol\%), sealed reactor, air, $\mathrm{MW}, 120^{\circ} \mathrm{C}, 1 \mathrm{~h}$.

' Reaction conditions (c): $\mathrm{Cs}_{2} \mathrm{CO}_{3}$ (2 equiv), $\mathrm{Pd}(\mathrm{OAc})_{2}$ (0.5 mol\%), Xantphos (2 mol\%), air, $100{ }^{\circ} \mathrm{C}, 12 \mathrm{~h}$.

In the product 15, $\mathrm{R}=\mathrm{p}$-(2-methylallyl).

Yields obtained were quite good to excellent for most products, which makes this process an easy way to provide various alkenes via an efficient palladium-catalyzed crosscoupling reaction. It is worth noting that a similar reactivity was observed for boronic acids substituted with an electron-withdrawing or an electron-donating group.

The outcomes were also indicative of the influence of the substituent position on the reactivity of the boronic acid. Comparing the same moiety, the $p$-substituted phenylboronic acid showed better reactivity than the respective $m$ - and $\boldsymbol{o}$-substituted phenylboronic acids. We observed deboronation side reactions for most of the 0 -substituted boronic acids when the cross-coupling reactions were performed at $140{ }^{\circ} \mathrm{C}$, but these side reactions could be avoided by using milder reaction conditions. Therefore, when mod- 
erate yields were obtained, the reaction conditions were slightly modified (mainly via lower temperature) in order to obtain yields of at least $70 \%$.

The assay carried out with a diboronic acid afforded the dicoupled product 15 in very good yield (77\%; Table 5, entry 14 ), which suggests the high reactivity of this substrate, as the two boronic moieties reacted with the same amount of catalyst and base as used for the examples with only one boronic moiety.

Surprisingly, a very low yield was observed for product 18 (Table 5, entry 17). We hypothesize that the hydroxymethyl group of the boronic acid likely interferes with palladium (oxidative addition to palladium) and cesium carbonate (organic salt formation), which results in a strongly decreased yield of the desired cross-coupled product.

Since we observed such low yields for compounds 1618 (Table 5, entries 15-17), we implemented a new assay: a solution of cesium carbonate, palladium(II) acetate and Xantphos in 2-methyl-2-propen-1-ol was first allowed to react, then the (hydroxymethyl)phenylboronic acid was added; the yields of alkenes obtained are listed in Table 6.

Table 6 Cross-Coupling Reactions with (Hydroxymethyl)phenylboronic Acids Using Conditions (d)

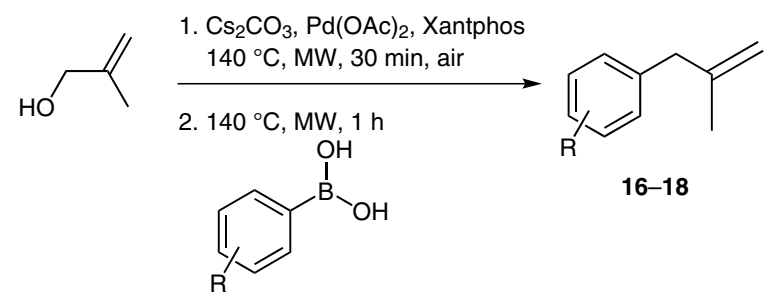

\begin{tabular}{llcl}
\hline Entry & $\mathrm{R}$ & Product & Yield (\%) \\
\hline 1 & $\mathrm{o}-\mathrm{CH}_{2} \mathrm{OH}$ & $\mathbf{1 6}$ & 84 \\
2 & $m-\mathrm{CH}_{2} \mathrm{OH}$ & $\mathbf{1 7}$ & 83 \\
3 & $p-\mathrm{CH}_{2} \mathrm{OH}$ & $\mathbf{1 8}$ & 90 \\
\hline
\end{tabular}

These very good yields confirm the previous hypothesis: cesium carbonate and palladium(II) acetate interact with the hydroxymethyl group of the boronic acid. Thus, a simple modification of the order of addition of the reagents led to the expected hydroxymethyl-containing products, with a greatly enhanced reactivity. It is worth noting that there is a hindrance effect, as a better yield was obtained with the $p$-hydroxymethyl substituent than with the $m$-hydroxymethyl and o-hydroxymethyl derivatives (Table 6).

In order to explore the scope of our reaction conditions, the reactivity of 2-methyl-3-buten-2-ol and 3-phenyl-2propen-1-ol were assessed: reactions with $p$-tolylboronic acid were implemented under microwave heating at $140{ }^{\circ} \mathrm{C}$ for 1.5 hours, using alternative allyl alcohols instead of methallyl alcohol. Alkenes 19 and 20, respectively, were obtained in moderate to good yields (Table 7).

Table 7 Cross-Coupling Reactions of $p$-Tolylboronic Acid with Other Allyl Alcohols ${ }^{\mathrm{a}}$

\begin{tabular}{llcc}
\hline Entry & Alcohol & Product & Yield (\%) \\
\hline 1 & 19 & 46 \\
\end{tabular}

${ }^{a}$ Reaction conditions (a): $p$-tolylboronic acid (1.2 equiv), $\mathrm{Cs}_{2} \mathrm{CO}_{3}$ (2 equiv), $\mathrm{Pd}(\mathrm{OAc})_{2}$ (0.5 mol\%), Xantphos (2 mol\%), air, MW, $140{ }^{\circ} \mathrm{C}, 1.5 \mathrm{~h}$.

These results suggest that this kind of cross-coupling reaction under our reaction conditions could be easily expanded to other allyl alcohols.

Based on our experimental results and previous studies, a mechanism is suggested. First, allyl alcohol activated by coordination of the hydroxy group with the arylboronic acid (A) undergoes oxidative addition to palladium $(0)$ through the allyl bond, to provide a cationic $\pi$-allylpalladi-

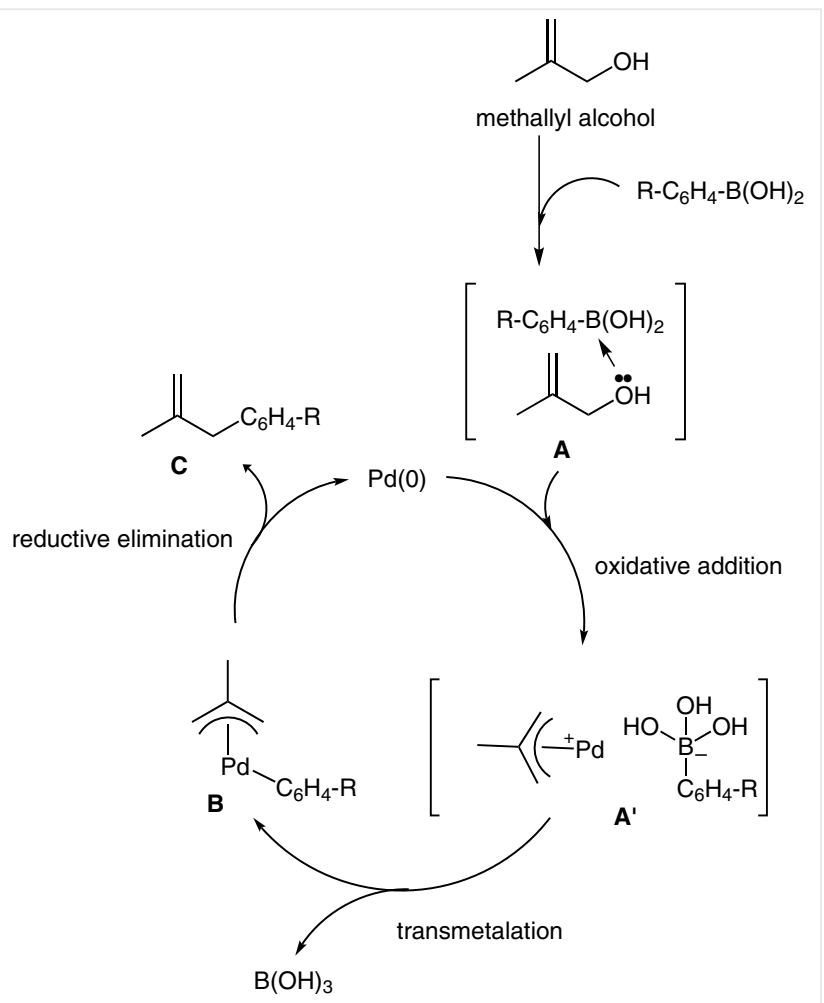

Scheme 3 Plausible catalytic cycle mechanism 
um intermediate $\left(\mathbf{A}^{\prime}\right)$. Then, this complex undergoes transmetalation to give diorganopalladium complex $\mathbf{B}$. Reductive elimination finally affords the coupled product $\mathbf{C}$ (Scheme 3). ${ }^{7}$

In conclusion, we have developed an easy and environmentally friendly way to synthesize 2-methylallyl alkenes via cross-coupling reactions between 2-methyl-2-propen1-ol and various arylboronic acids. Firstly, this study has shown that no additive solvent is required to carry out this kind of reaction. Moreover, the reaction offers greater atom economy than other classical cross-coupling reactions: the methallyl alcohol used as a solvent can be recycled for further cross-coupling reactions; very low amounts of palladium $(0.05 \mathrm{~mol} \%)$ are sufficient to catalyze the reaction (Table 4 , entry 4 ), even if $0.5 \mathrm{~mol} \%$ of palladium is used under the optimized conditions. Secondly, we have shown that this new process exhibits a high functional group tolerance, being reproducible for a wide range of arylboronic acids (such as those with a hydroxymethyl group that constitute a real challenge). These outcomes open up new prospects for the formation of carbon-carbon bonds in general (since the hydroxy group is much less toxic and more accessible than halide groups), and the synthesis of terminal alkenes in particular. Complementary studies to explore this original mechanism are ongoing.

TLC was performed on Merck aluminum plates $(5 \times 10 \mathrm{~cm})$ coated with silica gel $60 \mathrm{~F}_{254}$ (0.2-mm layer), using an appropriate solvent. Melting points were determined in capillary tubes using a Büchi B540 melting point apparatus. ${ }^{1} \mathrm{H}$ NMR and ${ }^{13} \mathrm{C}$ NMR spectra were recorded in $\mathrm{CDCl}_{3}$ or DMSO- $d_{6}$, with tetramethylsilane (TMS) as an internal reference using a Bruker ARX 200 spectrometer (operating at $200 \mathrm{MHz}$ for ${ }^{1} \mathrm{H}$ NMR and $50 \mathrm{MHz}$ for ${ }^{13} \mathrm{C}$ NMR), a Bruker Avance III NanoBay $300-\mathrm{MHz}$ spectrometer (operating at $300 \mathrm{MHz}$ for ${ }^{1} \mathrm{H}$ NMR and $75 \mathrm{MHz}$ for ${ }^{13} \mathrm{C}$ NMR), and a Bruker Avance III NanoBay $400-\mathrm{MHz}$ spectrometer (operating at $400 \mathrm{MHz}$ for ${ }^{1} \mathrm{H}$ NMR and $101 \mathrm{MHz}$ for ${ }^{13} \mathrm{C}$ NMR) at the Service Interuniversitaire de RMN de la Faculté de Pharmacie de Marseille or the Spectropole de la Faculté des Sciences site Saint-Jérôme. ${ }^{1} \mathrm{H}$ NMR chemical shifts are quoted in parts per million as $\delta$ downfield from TMS $(\delta 0.00)$ as an internal standard, and the ${ }^{13} \mathrm{C}$ NMR chemical shifts were referenced to the solvent peaks: $\mathrm{CDCl}_{3}$ $(76.9 \mathrm{ppm})$ or DMSO- $d_{6}(39.6 \mathrm{ppm})$. Coupling constants (J values) are given in hertz. NMR multiplicities are abbreviated as follows: $s$ (singlet), d (doublet), t (triplet), q (quartet) and $\mathrm{m}$ (a more complex multiplet or overlapping multiplets). Microwave-assisted Suzuki-Miyaura cross-coupling reactions were performed in a monomode microwave oven (Biotage Initiator microwave oven using $10-20-\mathrm{mL}$ or $2-5-\mathrm{mL}$ sealed vials; temperatures were measured with an IR sensor and reaction times given as hold times). Elemental analysis and mass spectra, run on an API-QqTOF mass spectrometer, were carried out at the Spectropole de la Faculté des Sciences site Saint-Jérôme. All commercial reagents were used without purification.

\section{(2-Methylallyl)benzene Derivatives 1-20}

\section{General Procedure for Reaction Conditions (a)}

Conditions (a): sealed reactor, air, MW, $140{ }^{\circ} \mathrm{C}, 1.5 \mathrm{~h}$.
A solution of 2-methyl-2-propen-1-ol ( $5 \mathrm{~mL})$, a boronic acid (4.1 mmol, 1.2 equiv), $\mathrm{Pd}(\mathrm{OAc})_{2}$ ( $3.8 \mathrm{mg}, 0.017 \mathrm{mmol}, 0.005$ equiv), Xantphos (38 mg, $0.068 \mathrm{mmol}, 0.02$ equiv) and $\mathrm{Cs}_{2} \mathrm{CO}_{3}(2.3 \mathrm{~g}, 7 \mathrm{mmol}, 2$ equiv) was stirred in a sealed vial for $1.5 \mathrm{~h}$ at $140{ }^{\circ} \mathrm{C}$, under microwave irradiation. Then, the solid residue was removed by filtration, and the filtrate was purified by distillation to obtain the alkene product.

\section{General Procedure for Reaction Conditions (b)}

Conditions (b): sealed reactor, air, MW, $120^{\circ} \mathrm{C}, 1 \mathrm{~h}$.

A solution of 2-methyl-2-propen-1-ol ( $5 \mathrm{~mL}$ ), a boronic acid (4.1 $\mathrm{mmol}, 1.2$ equiv), $\mathrm{Pd}(\mathrm{OAc})_{2}$ ( $3.8 \mathrm{mg}, 0.017 \mathrm{mmol}, 0.005$ equiv), Xantphos (38 mg, $0.068 \mathrm{mmol}, 0.02$ equiv) and $\mathrm{Cs}_{2} \mathrm{CO}_{3}(2.3 \mathrm{~g}, 7 \mathrm{mmol}, 2$ equiv) was stirred in a sealed vial for $1 \mathrm{~h}$ at $120^{\circ} \mathrm{C}$, under microwave irradiation. Then, the solid residue was removed by filtration, and the filtrate was purified by distillation to obtain the alkene product.

\section{General Procedure for Reaction Conditions (c)}

Conditions (c): air, $100{ }^{\circ} \mathrm{C}, 12 \mathrm{~h}$.

A solution of 2-methyl-2-propen-1-ol ( $5 \mathrm{~mL}$ ), a boronic acid (4.1 mmol, 1.2 equiv), $\mathrm{Pd}(\mathrm{OAc})_{2}$ ( $3.8 \mathrm{mg}, 0.017 \mathrm{mmol}, 0.005$ equiv), Xantphos (38 mg, $0.068 \mathrm{mmol}, 0.02$ equiv) and $\mathrm{Cs}_{2} \mathrm{CO}_{3}(2.3 \mathrm{~g}, 7 \mathrm{mmol}, 2$ equiv) was stirred in a sealed vial for $12 \mathrm{~h}$ at $100^{\circ} \mathrm{C}$. Then, the solid residue was removed by filtration, and the filtrate was purified by distillation to obtain the alkene product.

\section{General Procedure for Reaction Conditions (d)}

Conditions (d): sealed reactor, air, $\mathrm{MW}, 140{ }^{\circ} \mathrm{C}, 1.5 \mathrm{~h} ; 2$ steps.

A solution of 2-methyl-2-propen-1-ol (6 mL), $\mathrm{Pd}(\mathrm{OAc})_{2}$ (7.6 mg, 0.034 mmol, 0.005 equiv), Xantphos ( $76 \mathrm{mg}, 0.136 \mathrm{mmol}, 0.02$ equiv) and $\mathrm{Cs}_{2} \mathrm{CO}_{3}$ (2.3 g, $7 \mathrm{mmol}, 1$ equiv) was stirred in a sealed vial for $0.5 \mathrm{~h}$ at $140{ }^{\circ} \mathrm{C}$, under microwave irradiation. A boronic acid $(8.2 \mathrm{mmol}, 1.2$ equiv) was added to the reaction mixture which was then stirred in a sealed vial for $1 \mathrm{~h}$ at $140^{\circ} \mathrm{C}$, under microwave irradiation. Then, the solid residue was removed by filtration, and the filtrate was purified by distillation to obtain the alkene product.

\section{(2-Methylallyl)benzene (1) ${ }^{14}$}

Obtained from phenylboronic acid (500 $\mathrm{mg}$ ) using method (a), as a colorless oil; yield: $450 \mathrm{mg}$ (88\%); bp $178{ }^{\circ} \mathrm{C} / 760$ torr.

${ }^{1} \mathrm{H}$ NMR $\left(400 \mathrm{MHz}, \mathrm{CDCl}_{3}\right.$ ): $\delta=7.33-7.20(\mathrm{~m}, 5 \mathrm{H}), 4.83(\mathrm{~s}, 1 \mathrm{H}), 4.76$ (s, $1 \mathrm{H}), 3.28(\mathrm{~s}, 2 \mathrm{H}), 1.64(\mathrm{~s}, 3 \mathrm{H})$.

${ }^{13} \mathrm{C}$ NMR (101 MHz, $\mathrm{CDCl}_{3}$ ): $\delta=142.3$ (C), $139.8(\mathrm{C}), 128.9(2 \mathrm{CH})$, $128.3(2 \mathrm{CH}), 126.1(\mathrm{CH}), 111.9\left(\mathrm{CH}_{2}\right), 44.7\left(\mathrm{CH}_{2}\right), 22.1\left(\mathrm{CH}_{3}\right)$.

HRMS (ESI+): $m / z$ [M] $]^{+}$calcd for $\mathrm{C}_{10} \mathrm{H}_{12}: 132.0939$; found: 132.0984 .

\section{1-Methyl-2-(2-methylallyl)benzene (2) ${ }^{7 a}$}

Obtained from $o$-tolylboronic acid $(623 \mathrm{mg})$ using method (a), as a colorless oil; yield: $570 \mathrm{mg}(86 \%)$; bp $156{ }^{\circ} \mathrm{C} / 760$ torr.

${ }^{1} \mathrm{H}$ NMR (200 MHz, $\left.\mathrm{CDCl}_{3}\right): \delta=7.15(\mathrm{~s}, 4 \mathrm{H}), 4.83(\mathrm{~s}, 1 \mathrm{H}), 4.54(\mathrm{~s}, 1 \mathrm{H})$, $3.33(\mathrm{~s}, 2 \mathrm{H}), 2.29(\mathrm{~s}, 3 \mathrm{H}), 1.76(\mathrm{~s}, 3 \mathrm{H})$.

${ }^{13} \mathrm{C}$ NMR (50 MHz, $\mathrm{CDCl}_{3}$ ): $\delta=144.2$ (C), 137.9 (C), 136.8 (C), 130.1 (CH), $129.8(\mathrm{CH}), 126.3(\mathrm{CH}), 125.8(\mathrm{CH}), 111.6\left(\mathrm{CH}_{2}\right), 41.8\left(\mathrm{CH}_{2}\right), 22.7$ $\left(\mathrm{CH}_{3}\right), 19.4\left(\mathrm{CH}_{3}\right)$.

HRMS (ESI+): $m / z$ [M] $]^{+}$calcd for $\mathrm{C}_{11} \mathrm{H}_{14}$ : 146.1096; found: 146.1458 . 


\section{1-Methyl-3-(2-methylallyl)benzene (3)}

Obtained from $m$-tolylboronic acid (623 $\mathrm{mg}$ ) using method (b), as a colorless oil; yield: $490 \mathrm{mg}$ (74\%); bp $148^{\circ} \mathrm{C} / 760$ torr.

${ }^{1} \mathrm{H}$ NMR $\left(200 \mathrm{MHz}, \mathrm{CDCl}_{3}\right): \delta=7.25-6.89(\mathrm{~m}, 4 \mathrm{H}), 4.82(\mathrm{~s}, 1 \mathrm{H}), 4.75$ (s, $1 \mathrm{H}), 3.30$ (s, $2 \mathrm{H}), 2.35$ (s, $3 \mathrm{H}), 1.69(\mathrm{~s}, 3 \mathrm{H})$.

${ }^{13} \mathrm{C}$ NMR (50 MHz, $\mathrm{CDCl}_{3}$ ): $\delta=145.3$ (C), 139.7 (C), 137.8 (C), 129.7 $(\mathrm{CH}), 128.2(\mathrm{CH}), 126.8(\mathrm{CH}), 126.0(\mathrm{CH}), 111.8\left(\mathrm{CH}_{2}\right), 44.6\left(\mathrm{CH}_{2}\right), 22.1$ $\left(\mathrm{CH}_{3}\right), 21.4\left(\mathrm{CH}_{3}\right)$.

HRMS (ESI+): $m / z$ [M] ${ }^{+}$calcd for $\mathrm{C}_{11} \mathrm{H}_{14}$ : 146.1096; found: 146.1458 .

\section{1-Methyl-4-(2-methylallyl)benzene (4) ${ }^{7 a}$}

Obtained from $p$-tolylboronic acid (557 mg) using method (a) [yield: $600 \mathrm{mg}$ (100\%)], or from 2,4,6-tri-p-tolyl-1,3,5,2,4,6-trioxatriborinane $(1450 \mathrm{mg}$ ) using method (a), as a colorless oil; yield: $600 \mathrm{mg}$ (100\%); bp $177^{\circ} \mathrm{C} / 760$ torr.

${ }^{1} \mathrm{H} \mathrm{NMR}\left(200 \mathrm{MHz}, \mathrm{CDCl}_{3}\right): \delta=7.10(\mathrm{~s}, 4 \mathrm{H}), 4.80(\mathrm{~s}, 1 \mathrm{H}), 4.74(\mathrm{~s}, 1 \mathrm{H})$, 3.29 (s, $2 \mathrm{H}), 2.34$ (s, $3 \mathrm{H}), 1.69$ (s, $3 \mathrm{H})$.

${ }^{13} \mathrm{C} \mathrm{NMR} \mathrm{(50} \mathrm{MHz,} \mathrm{CDCl}_{3}$ ): $\delta=145.4(\mathrm{C}), 136.7$ (C), 135.5 (C), $129.0(2$ $\mathrm{CH}), 128.8(2 \mathrm{CH}), 111.7\left(\mathrm{CH}_{2}\right), 44.3\left(\mathrm{CH}_{2}\right), 22.1\left(\mathrm{CH}_{3}\right), 21.1\left(\mathrm{CH}_{3}\right)$.

HRMS (ESI+): $m / z$ [M] $]^{+}$calcd for $\mathrm{C}_{11} \mathrm{H}_{14}$ : 146.1096; found: 146.1141 .

\section{1-Bromo-2-(2-methylallyl)benzene (5)}

Obtained from 2-bromophenylboronic acid (823 mg) using method (b), as a colorless oil; yield: $700 \mathrm{mg}(81 \%)$; bp $157^{\circ} \mathrm{C} / 760$ torr.

${ }^{1} \mathrm{H}$ NMR $\left(200 \mathrm{MHz}, \mathrm{CDCl}_{3}\right.$ ): $\delta=7.68-6.76(\mathrm{~m}, 4 \mathrm{H}), 4.98(\mathrm{~s}, 1 \mathrm{H}), 4.90$ (s, $1 \mathrm{H}), 3.46(\mathrm{~s}, 2 \mathrm{H}), 1.76(\mathrm{~s}, 3 \mathrm{H})$.

${ }^{13} \mathrm{C}$ NMR (50 MHz, $\mathrm{CDCl}_{3}$ ): $\delta=143.5$ (C), 142.3 (C), 139.2 (C), 132.8 $(\mathrm{CH}), 130.9(\mathrm{CH}), 127.3(\mathrm{CH}), 126.9(\mathrm{CH}), 112.4\left(\mathrm{CH}_{2}\right), 43.9\left(\mathrm{CH}_{2}\right), 22.6$ $\left(\mathrm{CH}_{3}\right)$.

HRMS (ESI+): $m / z$ [M] $]^{+}$calcd for $\mathrm{C}_{10} \mathrm{H}_{11} \mathrm{Br}$ : 210.0044; found: 210.0078 .

\section{1-Bromo-4-(2-methylallyl)benzene (6)}

Obtained from 4-bromophenylboronic acid ( $823 \mathrm{mg}$ ) using method (a), as a colorless oil; yield: $800 \mathrm{mg}(92 \%)$; bp $158^{\circ} \mathrm{C} / 760$ torr.

${ }^{1} \mathrm{H}$ NMR $\left(200 \mathrm{MHz}, \mathrm{CDCl}_{3}\right): \delta=7.41(\mathrm{~d}, J=8.3 \mathrm{~Hz}, 2 \mathrm{H}), 7.07$ (d, $J=8.4$ Hz, 2 H), 5.07 (s, 1 H), 4.95 (s, 1 H), 4.02 (s, 2 H), 1.86 (s, 3 H).

${ }^{13} \mathrm{C} \mathrm{NMR}\left(50 \mathrm{MHz}, \mathrm{CDCl}_{3}\right): \delta=141.3(\mathrm{C}), 138.7(\mathrm{C}), 131.3(2 \mathrm{CH}), 130.7$ (2 $\mathrm{CH}), 119.9(\mathrm{C}), 115.2\left(\mathrm{CH}_{2}\right), 49.6\left(\mathrm{CH}_{2}\right), 22.0\left(\mathrm{CH}_{3}\right)$.

HRMS (ESI+): $m / z$ [M] ${ }^{+}$calcd for $\mathrm{C}_{10} \mathrm{H}_{11} \mathrm{Br}: 210.0044$; found: 210.0396.

\section{1-(2-Methylallyl)-2-nitrobenzene (7)}

Obtained from 2-nitrophenylboronic acid (684 mg) using method (c), as an orange oil; yield: $670 \mathrm{mg}(92 \%)$; bp $171{ }^{\circ} \mathrm{C} / 760$ torr.

${ }^{1} \mathrm{H}$ NMR (200 MHz, $\left.\mathrm{CDCl}_{3}\right): \delta=7.78(\mathrm{~m}, 4 \mathrm{H}), 4.96(\mathrm{~s}, 1 \mathrm{H}), 4.85(\mathrm{~s}, 1$ $\mathrm{H}), 3.86(\mathrm{~s}, 2 \mathrm{H}), 1.74(\mathrm{~s}, 3 \mathrm{H})$.

${ }^{13} \mathrm{C}$ NMR (50 MHz, $\mathrm{CDCl}_{3}$ ): $\delta=148.2(\mathrm{C}), 142.3(\mathrm{C}), 137.4(\mathrm{C}), 134.6$ $(\mathrm{CH}), 129.3(\mathrm{CH}), 123.5(2 \mathrm{CH}), 111.9\left(\mathrm{CH}_{2}\right), 73.8\left(\mathrm{CH}_{2}\right), 19.5\left(\mathrm{CH}_{3}\right)$. HRMS (ESI+): $m / z$ [M] $]^{+}$for $\mathrm{C}_{10} \mathrm{H}_{11} \mathrm{NO}_{2}$ : 177.0790; found: 177.0834 .

\section{1-(2-Methylallyl)-3-nitrobenzene (8)}

Obtained from 3-nitrophenylboronic acid (684 mg) using method (a), as a yellow oil; yield: $550 \mathrm{mg}(76 \%)$; bp $144^{\circ} \mathrm{C} / 760$ torr.

${ }^{1} \mathrm{H}$ NMR $\left(200 \mathrm{MHz}, \mathrm{CDCl}_{3}\right): \delta=8.05(\mathrm{~s}, 1 \mathrm{H}), 8.11-7.38(\mathrm{~m}, 3 \mathrm{H}), 4.88$ (s, $1 \mathrm{H}), 4.75(\mathrm{~s}, 1 \mathrm{H}), 3.41(\mathrm{~s}, 2 \mathrm{H}), 1.68(\mathrm{~s}, 3 \mathrm{H})$.
${ }^{13} \mathrm{C}$ NMR (50 MHz, $\mathrm{CDCl}_{3}$ ): $\delta=148.3$ (C), 143.5 (C), 141.8 (C), 135.1 $(\mathrm{CH}), 129.1(\mathrm{CH}), 123.7(\mathrm{CH}), 121.3(\mathrm{CH}), 113.3\left(\mathrm{CH}_{2}\right), 44.1\left(\mathrm{CH}_{2}\right), 22.0$ $\left(\mathrm{CH}_{3}\right)$.

HRMS (ESI+): $m / z[M]^{+}$calcd for $\mathrm{C}_{10} \mathrm{H}_{11} \mathrm{NO}_{2}$ : 177.0790; found: 177.1155.

\section{1-(2-Methylallyl)-4-nitrobenzene (9)}

Obtained from 4-nitrophenylboronic acid (684 mg) using method (a), as an orange oil; yield: $500 \mathrm{mg}$ (70\%); bp $170{ }^{\circ} \mathrm{C} / 760$ torr.

${ }^{1} \mathrm{H}$ NMR $\left(200 \mathrm{MHz}, \mathrm{CDCl}_{3}\right): \delta=8.14(\mathrm{~d}, J=8.7 \mathrm{~Hz}, 2 \mathrm{H}), 7.34(\mathrm{~d}, J=8.5$ $\mathrm{Hz}, 2 \mathrm{H}), 4.88$ (s, $1 \mathrm{H}), 4.74$ (s, $1 \mathrm{H}), 3.41$ (s, $2 \mathrm{H}), 1.67$ (s, $3 \mathrm{H})$.

${ }^{13} \mathrm{C}$ NMR (50 MHz, $\mathrm{CDCl}_{3}$ ): $\delta=147.6(\mathrm{C}), 146.6(\mathrm{C}), 143.4(\mathrm{C}), 129.7(2$ $\mathrm{CH}), 123.6(2 \mathrm{CH}), 113.4\left(\mathrm{CH}_{2}\right), 44.3\left(\mathrm{CH}_{2}\right), 22.1\left(\mathrm{CH}_{3}\right)$.

HRMS (ESI+): $m / z[M]^{+}$calcd for $\mathrm{C}_{10} \mathrm{H}_{11} \mathrm{NO}_{2}$ : 177.0790; found: 177.1153.

\section{4-(2-Methylallyl)-1,1'-biphenyl (10 $)^{15}$}

Obtained from 1,1'-biphenyl-4-ylboronic acid ( $812 \mathrm{mg})$ using method (a), as a colorless oil; yield: $800 \mathrm{mg}(94 \%)$; bp $225^{\circ} \mathrm{C} / 760$ torr.

${ }^{1} \mathrm{H}$ NMR (200 MHz, $\mathrm{CDCl}_{3}$ ): $\delta=7.67-7.27(\mathrm{~m}, 9 \mathrm{H}$ ), $4.88(\mathrm{~s}, 1 \mathrm{H}$ ), 4.82 (s, $1 \mathrm{H}), 3.39$ (s, $2 \mathrm{H}), 1.75$ (s, $3 \mathrm{H})$.

${ }^{13} \mathrm{C} \mathrm{NMR}\left(50 \mathrm{MHz}, \mathrm{CDCl}_{3}\right.$ ): $\delta=141.3$ (C), 141.1 (C), 139.1 (C), 138.9 (C), $129.4(\mathrm{~s}, 2 \mathrm{CH}), 128.8(2 \mathrm{CH}), 127.3(\mathrm{CH}), 127.2(2 \mathrm{CH}), 127.1(2 \mathrm{CH})$, $112.1\left(\mathrm{CH}_{2}\right), 44.3\left(\mathrm{CH}_{2}\right), 22.2\left(\mathrm{CH}_{3}\right)$.

HRMS (ESI+): $m / z$ [M] ${ }^{+}$calcd for $\mathrm{C}_{16} \mathrm{H}_{16}$ : 208.1252; found: 208.1615 .

\section{2-(2-Methylallyl)benzonitrile (11)}

Obtained from 2-cyanophenylboronic acid (602 mg) using method (c), as a light yellow oil; yield: $440 \mathrm{mg}$ (68\%); bp $160{ }^{\circ} \mathrm{C} / 760$ torr.

${ }^{1} \mathrm{H}$ NMR $\left(200 \mathrm{MHz}, \mathrm{CDCl}_{3}\right): \delta=7.79-7.25(\mathrm{~m}, 4 \mathrm{H}), 4.88(\mathrm{~s}, 1 \mathrm{H}), 4.68$ (s, $1 \mathrm{H}), 3.54(\mathrm{~s}, 2 \mathrm{H}), 1.73(\mathrm{~s}, 3 \mathrm{H})$.

${ }^{13} \mathrm{C}$ NMR (50 MHz, $\mathrm{CDCl}_{3}$ ): $\delta=143.6$ (2 C), $143.0(2 \mathrm{C}), 132.8(\mathrm{CH})$, $132.7(\mathrm{CH}), 130.1(\mathrm{CH}), 126.8(\mathrm{CH}), 113.3\left(\mathrm{CH}_{2}\right), 42.6\left(\mathrm{CH}_{2}\right), 22.3\left(\mathrm{CH}_{3}\right)$. HRMS (ESI+): $m / z$ [M] $]^{+}$calcd for $\mathrm{C}_{11} \mathrm{H}_{11} \mathrm{~N}$ : 157.0891 ; found: 157.0937 .

\section{3-(2-Methylallyl)benzonitrile (12)}

Obtained from 3-cyanophenylboronic acid $(602 \mathrm{mg})$ using method (a), as a light yellow oil; yield: $550 \mathrm{mg}$ (85\%); bp $152^{\circ} \mathrm{C} / 760$ torr.

${ }^{1} \mathrm{H}$ NMR $\left(200 \mathrm{MHz}, \mathrm{CDCl}_{3}\right): \delta=7.74-7.31(\mathrm{~m}, 4 \mathrm{H}), 4.86(\mathrm{~s}, 1 \mathrm{H}), 4.72$ (s, $1 \mathrm{H}), 3.33(\mathrm{~s}, 2 \mathrm{H}), 1.65$ (s, $3 \mathrm{H})$.

${ }^{13} \mathrm{C}$ NMR (50 MHz, $\mathrm{CDCl}_{3}$ ): $\delta=143.6(2 \mathrm{C}), 141.2(2 \mathrm{C}), 133.5(\mathrm{CH})$, 132.2 (CH), $130.0(\mathrm{CH}), 129.1(\mathrm{CH}), 113.2\left(\mathrm{CH}_{2}\right), 44.0\left(\mathrm{CH}_{2}\right), 22.0\left(\mathrm{CH}_{3}\right)$. HRMS (ESI+): $m / z$ [M] $]^{+}$calcd for $\mathrm{C}_{11} \mathrm{H}_{11} \mathrm{~N}$ : 157.0891; found: 157.0964 .

\section{4-(2-Methylallyl)benzonitrile (13) ${ }^{7 \mathrm{c}}$}

Obtained from 4-cyanophenylboronic acid (602 mg) using method (a), as a colorless oil; yield: $612 \mathrm{mg}$ (95\%); bp $181^{\circ} \mathrm{C} / 760$ torr.

${ }^{1} \mathrm{H} \mathrm{NMR}\left(200 \mathrm{MHz}, \mathrm{CDCl}_{3}\right): \delta=7.58(\mathrm{~d}, J=8.2 \mathrm{~Hz}, 2 \mathrm{H}), 7.29$ (d, $J=8.2$ $\mathrm{Hz}, 2 \mathrm{H}), 4.86(\mathrm{~s}, 1 \mathrm{H}), 4.72(\mathrm{~s}, 1 \mathrm{H}), 3.36(\mathrm{~s}, 2 \mathrm{H}), 1.66(\mathrm{~s}, 3 \mathrm{H})$.

${ }^{13} \mathrm{C}$ NMR $\left(50 \mathrm{MHz}, \mathrm{CDCl}_{3}\right): \delta=145.4(2 \mathrm{C}), 143.6(2 \mathrm{C}), 132.2(2 \mathrm{CH})$, $129.7(2 \mathrm{CH}), 113.2\left(\mathrm{CH}_{2}\right), 44.6\left(\mathrm{CH}_{2}\right), 22.1\left(\mathrm{CH}_{3}\right)$.

HRMS (ESI+): $m / z$ [M] $]^{+}$calcd for $\mathrm{C}_{11} \mathrm{H}_{11} \mathrm{~N}$ : 157.0891; found: 157.0840 . Anal. Calcd for $\mathrm{C}_{11} \mathrm{H}_{11} \mathrm{~N}$ (157.0891): C, 84.04; H, 7.05; N, 8.91. Found: C, 83.78; H, 7.05; N, 9.11. 


\section{1-(2-Methylallyl)-4-vinylbenzene (14) ${ }^{16}$}

Obtained from 4-vinylphenylboronic acid (607 mg) using method (a), as a slight yellow oil; yield: $500 \mathrm{mg}(77 \%)$; bp $170{ }^{\circ} \mathrm{C} / 760$ torr.

${ }^{1} \mathrm{H}$ NMR $\left(200 \mathrm{MHz}, \mathrm{CDCl}_{3}\right): \delta=7.36(\mathrm{~d}, J=8.1 \mathrm{~Hz}, 2 \mathrm{H}), 7.17(\mathrm{~d}, J=8.1$ $\mathrm{Hz}, 2 \mathrm{H}), 6.72(\mathrm{dd}, J=17.6,10.9 \mathrm{~Hz}, 1 \mathrm{H}), 5.73(\mathrm{~d}, J=17.6 \mathrm{~Hz}, 1 \mathrm{H}), 5.22$ (d, J = $10.9 \mathrm{~Hz}, 1 \mathrm{H}), 4.83$ (s, $1 \mathrm{H}), 4.75$ (s, $1 \mathrm{H}), 3.32$ (s, $2 \mathrm{H}), 1.69$ (s, 3 $\mathrm{H})$.

${ }^{13} \mathrm{C}$ NMR (75 MHz, $\mathrm{CDCl}_{3}$ ): $\delta=142.3(\mathrm{C}), 139.5(\mathrm{C}), 136.7(\mathrm{CH}), 135.5$ (C), $129.1(2 \mathrm{CH}), 126.2(2 \mathrm{CH}), 113.1\left(\mathrm{CH}_{2}\right), 112.0\left(\mathrm{CH}_{2}\right), 44.4\left(\mathrm{CH}_{2}\right)$, $22.1\left(\mathrm{CH}_{3}\right)$.

HRMS (ESI+): $m / z$ [M] $]^{+}$calcd for $\mathrm{C}_{12} \mathrm{H}_{14}$ : 158.1096; found: 158.1140 .

\section{1,4-Bis(2-methylallyl)benzene (15)}

Obtained from 1,4-phenylenediboronic acid (150 mg) using method (a), as a colorless oil; yield: $130 \mathrm{mg}(77 \%)$; bp $158^{\circ} \mathrm{C} / 760$ torr.

${ }^{1} \mathrm{H}$ NMR (200 MHz, $\mathrm{CDCl}_{3}$ ): $\delta=7.11$ (s, $\left.4 \mathrm{H}\right), 4.81$ (s, $\left.2 \mathrm{H}\right), 4.74(\mathrm{~s}, 2 \mathrm{H})$, $3.30(\mathrm{~s}, 4 \mathrm{H}), 1.68(\mathrm{~s}, 6 \mathrm{H})$.

${ }^{13} \mathrm{C}$ NMR (75 MHz, $\mathrm{CDCl}_{3}$ ): $\delta=142.3$ (2 C), $137.4(2 \mathrm{C}), 128.8(4 \mathrm{CH})$, $112.0\left(2 \mathrm{CH}_{2}\right), 44.3\left(2 \mathrm{CH}_{2}\right), 22.1\left(2 \mathrm{CH}_{3}\right)$.

HRMS (ESI+): $m / z$ [M] ${ }^{+}$calcd for $\mathrm{C}_{14} \mathrm{H}_{18}$ : 186.1409; found: 186.1455 .

\section{[2-(2-Methylallyl)phenyl]methanol (16)}

Obtained from 2-(hydroxymethyl)phenylboronic acid (1000 mg) using method (d), as an opalescent oil; yield: $900 \mathrm{mg}$ (84\%); bp $185^{\circ} \mathrm{C} / 760$ torr

${ }^{1} \mathrm{H}$ NMR $\left(200 \mathrm{MHz}\right.$, DMSO- $\left.d_{6}\right): \delta=8.09-6.61(\mathrm{~m}, 4 \mathrm{H}), 5.01(\mathrm{t}, J=5.3$ $\mathrm{Hz}, 1 \mathrm{H}), 4.80(\mathrm{~s}, 1 \mathrm{H}), 4.56(\mathrm{~s}, 1 \mathrm{H}), 4.54(\mathrm{~d}, J=5.1 \mathrm{~Hz}, 2 \mathrm{H}), 3.35$ (s, 2 $\mathrm{H}), 1.69(\mathrm{~s}, 3 \mathrm{H})$.

${ }^{13} \mathrm{C}$ NMR (50 MHz, DMSO- $d_{6}$ ): $\delta=144.7$ (C), $141.0(\mathrm{C}), 136.7$ (C), 128.5 $(\mathrm{CH}), 127.4(\mathrm{CH}), 127.0(\mathrm{CH}), 126.5(\mathrm{CH}), 111.9\left(\mathrm{CH}_{2}\right), 60.9\left(\mathrm{CH}_{2}\right), 40.5$ $\left(\mathrm{CH}_{2}\right), 22.8\left(\mathrm{CH}_{3}\right)$.

HRMS (ESI+): $m / z$ [M] ${ }^{+}$calcd for $\mathrm{C}_{11} \mathrm{H}_{14} \mathrm{O}$ : 162.1045; found: 162.1990 .

\section{[3-(2-Methylallyl)phenyl]methanol (17)}

Obtained from 3-(hydroxymethyl)phenylboronic acid (1246 mg) using method (d), as a colorless oil; yield: $1100 \mathrm{mg}(83 \%)$; bp $178^{\circ} \mathrm{C} / 760$ torr.

${ }^{1} \mathrm{H}$ NMR $\left(200 \mathrm{MHz}\right.$, DMSO- $\left.d_{6}\right): \delta=7.41-6.92(\mathrm{~m}, 4 \mathrm{H}), 5.17(\mathrm{t}, J=5.7$ $\mathrm{Hz}, 1 \mathrm{H}), 4.77(\mathrm{~s}, 1 \mathrm{H}), 4.73(\mathrm{~s}, 1 \mathrm{H}), 4.49(\mathrm{~d}, J=5.5 \mathrm{~Hz}, 2 \mathrm{H}), 3.29(\mathrm{~s}, 2$ $\mathrm{H}), 1.62(\mathrm{~s}, 3 \mathrm{H})$.

${ }^{13} \mathrm{C}$ NMR (50 MHz, DMSO- $d_{6}$ ): $\delta=145.2(\mathrm{C}), 143.0(\mathrm{C}), 139.6(\mathrm{C}), 128.4$ $(\mathrm{CH}), 127.5(\mathrm{CH}), 127.2(\mathrm{CH}), 124.7(\mathrm{CH}), 112.3\left(\mathrm{CH}_{2}\right), 63.4\left(\mathrm{CH}_{2}\right), 44.4$ $\left(\mathrm{CH}_{2}\right), 22.3\left(\mathrm{CH}_{3}\right)$.

HRMS (ESI+): $m / z$ [M] $]^{+}$calcd for $\mathrm{C}_{11} \mathrm{H}_{14} \mathrm{O}: 162.1045$; found: 162.1090 .

\section{[4-(2-Methylallyl)phenyl]methanol (18)}

Obtained from 4-(hydroxymethyl)phenylboronic acid (1246 mg) using method (d), as a colorless oil; yield: $1200 \mathrm{mg}(90 \%)$; bp $175^{\circ} \mathrm{C} / 760$ torr.

${ }^{1} \mathrm{H}$ NMR $\left(200 \mathrm{MHz}\right.$, DMSO- $\left.d_{6}\right): \delta=7.25(\mathrm{~d}, J=7.8 \mathrm{~Hz}, 2 \mathrm{H}), 7.13(\mathrm{~d}, J=$ $7.9 \mathrm{~Hz}, 2 \mathrm{H}), 5.14(\mathrm{t}, J=5.7 \mathrm{~Hz}, 1 \mathrm{H}), 4.76(\mathrm{~s}, 1 \mathrm{H}), 4.71(\mathrm{~s}, 1 \mathrm{H}), 4.47$ (d, $J=5.9 \mathrm{~Hz}, 2 \mathrm{H}), 3.27(\mathrm{~s}, 2 \mathrm{H}), 1.61(\mathrm{~s}, 3 \mathrm{H})$.

${ }^{13} \mathrm{C}$ NMR (50 MHz, DMSO- $d_{6}$ ): $\delta=145.4(\mathrm{C}), 140.8(\mathrm{C}), 138.1(\mathrm{C}), 128.9$ $(2 \mathrm{CH}), 127.0(2 \mathrm{CH}), 112.2\left(\mathrm{CH}_{2}\right), 63.3\left(\mathrm{CH}_{2}\right), 44.0\left(\mathrm{CH}_{2}\right), 22.2\left(\mathrm{CH}_{3}\right)$. HRMS (ESI+): $m / z$ [M] $]^{+}$calcd for $\mathrm{C}_{11} \mathrm{H}_{14} \mathrm{O}: 162.1045$; found: 162.1090 .
Anal. Calcd for $\mathrm{C}_{11} \mathrm{H}_{14} \mathrm{O}$ (162.1045): C, 81.44; H, 8.70. Found: C, 81.34; H, 8.73.

1-Methyl-4-(2-methyl-3-buten-2-yl)benzene (19) ${ }^{17}$

Obtained from $p$-tolylboronic acid (557 $\mathrm{mg}$ ) using method (a), with 2methyl-3-buten-2-ol instead of 2-methyl-2-propen-1-ol, as a slight yellow oil; yield: $300 \mathrm{mg}(46 \%)$; bp $178^{\circ} \mathrm{C} / 760$ torr.

${ }^{1} \mathrm{H}$ NMR $\left(200 \mathrm{MHz}, \mathrm{CDCl}_{3}\right): \delta=7.77(\mathrm{~d}, J=8.6 \mathrm{~Hz}, 2 \mathrm{H}), 6.97(\mathrm{~d}, J=8.6$ $\mathrm{Hz}, 2 \mathrm{H}$ ), 6.00 (dd, $J=17.4,10.7 \mathrm{~Hz}, 1 \mathrm{H}$ ), 5.10 (ddd, $J=14.0,11.6,0.9$ $\mathrm{Hz}, 2 \mathrm{H}), 3.86$ (s, $3 \mathrm{H}), 1.32$ (s, $6 \mathrm{H})$.

${ }^{13} \mathrm{C}$ NMR (63 MHz, $\left.\mathrm{CDCl}_{3}\right): \delta=161.9(2 \mathrm{C}), 146.1(\mathrm{CH}), 136.7(2 \mathrm{CH})$, $113.5(2 \mathrm{CH}), 110.9\left(\mathrm{CH}_{2}\right), 71.2(\mathrm{C}), 55.2\left(2 \mathrm{CH}_{3}\right), 29.4\left(\mathrm{CH}_{3}\right)$.

HRMS (ESI+): $m / z$ [M] $]^{+}$calcd for $\mathrm{C}_{12} \mathrm{H}_{16}: 160.1252$; found: 160.1215 .

\section{1-Cinnamyl-4-methylbenzene $(20)^{7 \mathrm{~h}}$}

Obtained from $p$-tolylboronic acid (250 mg) using method (a), with 3phenyl-2-propen-1-ol instead of 2-methyl-2-propen-1-ol, as a white oil; yield: $360 \mathrm{mg}(94 \%)$.

${ }^{1} \mathrm{H}$ NMR $\left(200 \mathrm{MHz}, \mathrm{CDCl}_{3}\right): \delta=7.35-7.11(\mathrm{~m}, 9 \mathrm{H}), 6.47(\mathrm{~d}, J=15.5 \mathrm{~Hz}$, $1 \mathrm{H}), 6.41-6.27(\mathrm{~m}, 1 \mathrm{H}), 3.52(\mathrm{~d}, J=6.3 \mathrm{~Hz}, 2 \mathrm{H}), 2.34(\mathrm{~s}, 3 \mathrm{H})$.

${ }^{13} \mathrm{C}$ NMR (63 MHz, $\mathrm{CDCl}_{3}$ ): $\delta=137.5$ (C), 137.0 (C), 135.7 (C), 130.8 (CH), $129.5(\mathrm{CH}), 129.2(2 \mathrm{CH}), 128.6(2 \mathrm{CH}), 128.5(2 \mathrm{CH}), 127.0(\mathrm{CH})$, $126.1(2 \mathrm{CH}), 38.9\left(\mathrm{CH}_{2}\right), 21.0\left(\mathrm{CH}_{3}\right)$.

HRMS (ESI+): $m / z$ [M] $]^{+}$calcd for $\mathrm{C}_{16} \mathrm{H}_{16}: 208.1252$; found: 208.1315 .

\section{Acknowledgment}

This work was supported by the CNRS and Aix-Marseille University. The authors thank V. Monier and C. Chendo for mass spectra recording, and M. D. Crozet for fruitful discussions.

\section{References}

(1) (a) Control of the leishmaniases, World Health Organization Technical Report Series 949; WHO: Geneva, 2010, 1. (b) Alvar, J.; Vélez, I.; Bern, C.; Herrero, M.; Desjeux, P.; Cano, J.; Jannin, J.; Der Boer, M. PloS One 2012, 7, e35671.

(2) Monge-Maillo, B.; Lopez-Velez, R. Drugs 2013, 73, 1863.

(3) (a) Curti, C.; Crozet, M. D.; Vanelle, P. Tetrahedron 2009, 65, 200. (b) Bouhlel, A.; Curti, C.; Khoumeri, O.; Vanelle, P. Tetrahedron Lett. 2011, 52, 1919.

(4) (a) Bouhlel, A.; Curti, C.; Dumètre, A.; Laget, M.; Crozet, M. D.; Azas, N.; Vanelle, P. Bioorg. Med. Chem. 2010, 18, 7310. (b) Paloque, L.; Bouhlel, A.; Curti, C.; Dumètre, A.; Verhaeghe, P.; Azas, N.; Vanelle, P. Eur. J. Med. Chem. 2011, 46, 2984.

(5) Tabélé, C.; Cohen, A.; Curti, C.; Bouhlel, A.; Hutter, S.; Remusat, V.; Primas, N.; Terme, T.; Azas, N.; Vanelle, P. Eur. J. Med. Chem. 2014, 87, 440.

(6) (a) Crozet, M. P.; Archaimbault, G.; Vanelle, P.; Nouguier, R. Tetrahedron Lett. 1985, 26, 5133. (b) Vanelle, P.; Madadi, N.; Roubaud, C.; Maldonado, J.; Crozet, M. P. Tetrahedron 1991, 47, 5173. (c) Roubaud, C.; Vanelle, P.; Maldonado, J.; Crozet, M. P. Tetrahedron 1995, 51, 9643. (d) Gellis, A.; Vanelle, P.; Kaafarani, M.; Benakli, K.; Crozet, M. P. Tetrahedron 1997, 53, 5471. (e) Crozet, M. D.; Botta, C.; Gasquet, M.; Curti, C.; Remusat, V.; Hutter, S.; Chapelle, O.; Azas, N.; De Meo, M.; Vanelle, P. Eur. J. Med. Chem. 2009, 44, 653. (f) Verhaeghe, P.; Azas, N.; Hutter, S.; 
Castera-Ducros, C.; Laget, M.; Dumètre, A.; Gasquet, M.; Reboul, J. P.; Rault, S.; Rathelot, P.; Vanelle, P. Bioorg. Med. Chem. 2009, $17,4313$.

(7) (a) Volla, C. M. R.; Marković, D.; Dubbaka, S. R.; Vogel, P. Eur. J. Org. Chem. 2009, 6281. (b) Yasuda, S.; Yorimitsu, H.; Oshima, K. Organometallics 2008, 27, 4025. (c) Yasuda, S.; Asada, Y.; Yorimitsu, H.; Oshima, K. Materials 2009, 2, 978. (d) Iwasaki, M.; Hayashi, S.; Hirano, K.; Yorimitsu, H.; Oshima, K. Tetrahedron 2007, 63, 5200. (e) Cui, X.; Wang, S.; Zhang, Y.; Deng, W.; Qian, Q.; Gong, H. Org. Biomol. Chem. 2013, 11, 3094. (f) Tsukamoto, H.; Sato, M.; Kondo, Y. Chem. Commun. 2004, 1200. (g) Kayaki, Y.; Koda, T.; Ikariya, T. Eur. J. Org. Chem. 2004, 4989. (h) Tsukamoto, H.; Uchiyama, T.; Suzuki, T.; Kondo, Y. Org. Biomol. Chem. 2008, 6, 3005. (i) Wu, H. B.; Ma, X. T.; Tian, S. K. Chem. Commun. 2014, 50, 219. (j) Ye, J.; Zhao, J.; Xu, J.; Mao, Y.; Zhang, Y. J. Chem. Commun. 2013, 49, 9761.

(8) Manabe, K.; Nakada, K.; Aoyama, N.; Kobayashi, S. Adv. Synth. Catal. 2005, 347, 1499.

(9) (a) Kabri, Y.; Gellis, A.; Vanelle, P. Eur. J. Org. Chem. 2009, 4059. (b) Kabri, Y.; Crozet, M. D.; Szabo, R.; Vanelle, P. Synthesis 2011, 3115. (c) Kabri, Y.; Crozet, M. D.; Primas, N.; Vanelle, P. Eur. J.
Org. Chem. 2012, 5595. (d) Cohen, A.; Crozet, M. D.; Rathelot, P.; Vanelle, P. Green Chem. 2009, 11, 1736. (e) Crozet, M. D.; Castera-Ducros, C.; Vanelle, P. Tetrahedron Lett. 2006, 47, 7061.

(10) Eric, E.; Feixia, C.; Seok, I.; Kyung, W. Tetrahedron Lett. 1999, 40, 1843.

(11) Baxter, J.; Steinhuebel, D.; Palucki, M.; Davies, I. Org. Lett. 2005, 7, 215.

(12) Abdul Khader, K. K.; Sajith, A. M.; Ali Padusha, M. S.; Nagaswarupa, H. P.; Muralidharan, A. New J. Chem. 2014, 38, 1294.

(13) McLaughlin, M. Org. Lett. 2005, 7, 4875.

(14) Baralle, A.; Fensterbank, L.; Goddard, J. P.; Ollivier, C. Chem. Eur. J. 2013, 19, 10809.

(15) Takeda, T.; Obata, R.; Muramatsu, D.; Takeda, Y.; Tsubouchi, A. Chem. Commun. 2014, 50, 15156.

(16) Hirao, A.; Kubota, S.; Sueyoshi, T.; Sugiyama, K. Macromol. Chem. Phys. 2001, 202, 1044.

(17) Mayer, M.; Czaplik, W. M.; Jacobi von Wangelin, A. Adv. Synth. Catal. 2010, 352, 2147. 